\title{
Preliminary Assessment of the Potential for Mangrove Oyster Cultivation in Piraquê-açu River Estuary (Aracruz, ES)
}

\section{Luciana Alvarenga* and Rosebel Cunha Nalesso}

Departamento de Ecologia e Recursos Naturais; Universidade Federal do Espírito Santo; Av. Fernando Ferrari, 514; 29075-910, Vitória - ES - Brasil. Faculdade Espírito Santense de Administração (FAESA); Rodovia Serafim Derenzi, 33115; Vitória - ES - Brasil

\begin{abstract}
At Piraquê-açu river estuary, Aracruz, ES, the technical viability of Crassostrea rhizophorae cultivation was determined through monthly measures in shell length and weight. Seeds of C. rhizophorae were put in cages and suspended in rafts. Increase in height and weight (flesh and dry) of the oysters was measured. During ten months (July/98 to May/99), oyster shell reached an average of $37.6 \mathrm{~mm}$ in shell height and $3.0 \mathrm{~g}$ in flesh weight (the whole animal). High mortality rates were registered and could be related to the high salinity water and to high predation observed, especially by flatworms Stylochophana divae and snails Cymatium parthenopeum, as well as fouling organisms such as barnacles, Serpulidae polychaetes and seed of the same species.
\end{abstract}

Key words: Mangrove oyster, Crassostrea rhizophorae, fouling

\section{INTRODUCTION}

In Brazil, oyster production has increased since the introduction of Crassostrea gigas in Santa Catarina State, which is the main Brazilian oyster producer, with one million dozen of oysters harvested in 2000 (Barardi and Santos, 2001). Constraints in $C$. gigas cultivation, mainly because it is an exotic species from temperate climates, has led to increased studies of the native mangrove oyster, Crassostrea rhizophorae (Fiperj, 1997).

The mangrove oyster, $C$. rhizophorae, is typical of tropical areas, occurring mainly on aerial roots of the red mangrove, Rhizophora mangle or in intertidal rocky shores (Nascimento, 1982). But there is much controversy about the genus in Brazil: Pereira et al., (1988) and Nascimento
(1991) recognised that $C$. brasiliana was distinct from $C$. rhizophorae, because the former was larger and was always found in subtidal mangrove channels, while the latter was smaller and inhabited intertidal zones. Rios (1994) considered C. brasiliana a synonym of $C$. rhizophorae. Ignacio et al. (2000), through allozyme electrophoresis, found that even sympatric populations from both forms of Crassostrea, were different enough to be considered a distinct species, but populations of $C$. rhizophorae collected from distant locations were found to be very similar.

In Espírito Santo State, oyster harvesting from natural populations is an important local activity, mainly carried out by fishermen (or poor coastal dwellers) during summer time, when tourism

\footnotetext{
* Author for correspondence
} 
increases market demand. However, the high demand for oysters, the indiscriminate harvest and perhaps mainly pollution due to the discharge of waste water (Carmo, 1987), threaten production and the recovery of the wild stocks. Lemos et al., (1994) and Miranda and Guzenski (1999) stated that oyster culture was the solution to the superexploitation of natural oyster beds.

The aim of this work was to evaluate the technical viability of the cultivation of $C$. rhizophorae, as an alternative source of income to fisherman from Piraquê-açu river estuary, Aracruz district, in Espírito Santo State, south-eastern Brazil.

\section{MATERIALS AND METHODS}

Piraquê-açu River estuary $\left(19^{\circ} 56^{\prime} 52^{\prime} ' \mathrm{~S}\right.$ and $40^{\circ}$ 9'31' 'W) belongs to Aracruz district, ES (Fig. 1). The experimental cultivation of Crassostrea rhizophorae was installed on a raft from Aracruz District Council and Centro de Tecnologia em Aquicultura - CTA (CTA, 1996). Previous attempt to collect seeds on that estuary failed, hence seeds collected at intertidal levels at São Francisco River estuary, Pacatuba District, Sergipe State, were used.

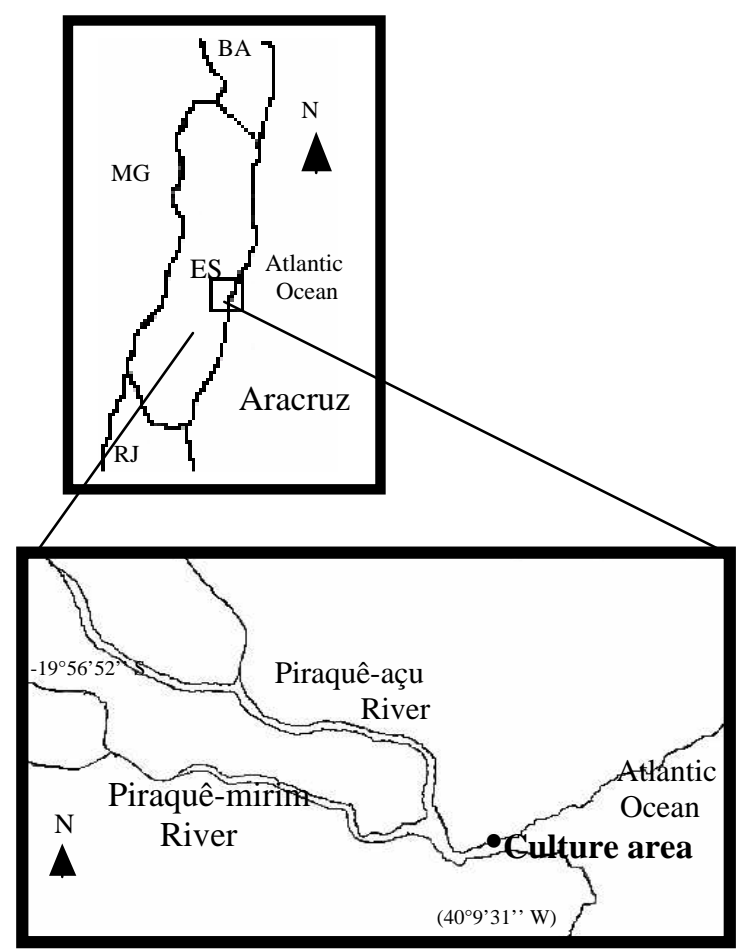

Figure 1 - Location of culture area at Piraquê-açu river estuary $(1 \mathrm{~cm}=1.25 \mathrm{~km})$.
In July/98, seeds were put in one nursery cage (with a mesh of $1.5 \mathrm{~mm}$ ) with five levels. Five hundred seeds were put in each level equating to 2,500 oysters in a cage. When the seeds reached $30 \mathrm{~mm}$, they were transferred to an intermediary cage (with a mesh of $5 \mathrm{~mm}$ ). The cages were suspended by a rope on the raft at a depth of 80 $\mathrm{cm}$. Monthly samples of 80 oysters (40 in the last month) were brought to the laboratory and shell height, length and thickness were measured (according Galtsoff, 1964) using a Vernier caliper. The whole oyster weight, weight of the wet meat and weight of the dry meat (after drying in an oven $60^{\circ} \mathrm{C}$ for $24 \mathrm{~h}$ ) were also recorded. Dead oysters were recorded but not included in the biometry. Mean monthly instantaneous growth rate (IGR) was calculated from the formula:

IGR $=10 \log _{\mathrm{e}}\left(\mathrm{L}_{2}\right)-\log _{\mathrm{e}}\left(\mathrm{L}_{1}\right) /\left(\mathrm{t}_{2}-\mathrm{t}_{1}\right)$ (Ricker, 1975), where $L_{2}$ is the final length, $L_{1}$ is the initial length, and $t_{2}-t_{1}$ is the duration of the growth period in days.

Fouling organisms both from the cages and the oysters were removed by brushing every month. Fouling organisms from the sampled oysters were quantified and identified to the nearest taxonomic level possible, including seeds of $C$. rhizophorae recruited locally, which were also measured for height. Dissolved oxygen, temperature and salinity were recorded in situ next to the raft using a multiparameter device (YSI 85); $\mathrm{pH}$ measurements were carried out in the laboratory.

\section{RESULTS}

At the beginning of the experiment, the oyster seeds were $6.16 \pm 0.97 \mathrm{~mm}$ in height with a whole weight of $0.02 \pm 0.01 \mathrm{~g}$. After ten months, they reached $37.58 \pm 8.0 \mathrm{~mm}$ in height, $18.97 \pm 2.9 \mathrm{~mm}$ in length and $8.14 \pm 2.5 \mathrm{~mm}$ in thickness (Fig. 2), with a whole weight of $3.0 \pm 0.94 \mathrm{~g}$. After ten months, the wet meat increased to $0.33 \pm 0.09 \mathrm{~g}$ and the dry meat $0.04 \pm 0.01 \mathrm{~g}$, with a decrease in March (Fig. 3). The mean monthly instantaneous growth rate fell exponentially and after the fifth month, there was nearly no growth (Fig. 4). From December on (fifth month), there was increased fouling on the oyster shell, primarily by barnacles such as Chthamalus bisinuatus, tubes of Serpulidae polychaetes, mussels Brachidontes darwinianus, bryozoans and ascideans, as well as seeds of $C$. rhizophorae, reaching a maximum 
density in May (Fig. 5). The encrusted seeds of $C$. rhizophorae varied from 1.4 to $42 \mathrm{~mm}$ in height. In the first months, the mortality was very low, but from November on, the oysters started to die, with $55 \%$ mortality by the end of the experiment (Fig. 6). In May, from the remaining 40 oysters in the cage, only 18 were alive, seven of them had flatworms Stylochophana divae inside the shells; three predator snails Cymatium parthenopeum were also found in this sample.

Water salinity near the raft varied from 26 to 36 psu, temperature from 22 to $28.6^{\circ} \mathrm{C}$, dissolved oxygen from 5.4 to $9.6 \mathrm{mg} . \mathrm{L}^{-1}$ and $\mathrm{pH}$ from 6.9 to 8.4 (Table 1). There was no correlation among the physico-chemical parameters of water and oysters mortality.

\section{DISCUSSION}

At Piraquê-açu river estuary, oysters reached an average height of $37.58 \mathrm{~mm}$ in ten months. This growth could be considered quite low when compared with other areas. In Cuba, Vélez (1991) reported growth of up to $50 \mathrm{~mm}$ of $C$. rhizophorae in five to six months of cultivation using intertidal rafts, with growth of between 70 and $80 \mathrm{~mm}$ on subtidal rafts in a similar period of time. In other estuaries, such as the Itapessoca river estuary, in Pernambuco State, this species reached $46 \mathrm{~mm}$ after one year of cultivation (Nascimento et al., 1980).

Table 1 - Range (minimum-maximum) of the physico-chemical parameters of culture water at Piraquê-açu river estuary.

\begin{tabular}{lcccc}
\hline & winter & spring & summer & autumn \\
\hline Salinity $(\mathrm{psu})$ & $35-36$ & $26-36$ & $35-35.5$ & $30-36$ \\
Temperature $\left({ }^{\circ} \mathrm{C}\right)$ & $22-22.5$ & $22-25$ & $24-28.6$ & $24-24.5$ \\
$\mathrm{O}_{2}\left(\mathrm{mg} . \mathrm{L}^{-1}\right)$ & $6-9.6$ & $6.2-7.6$ & $7.7-7.8$ & $5.4-5.7$ \\
$\mathrm{pH}$ & $6.9-8.4$ & $7.1-7.2$ & $7.8-7.9$ & $6.8-8.5$ \\
\hline
\end{tabular}

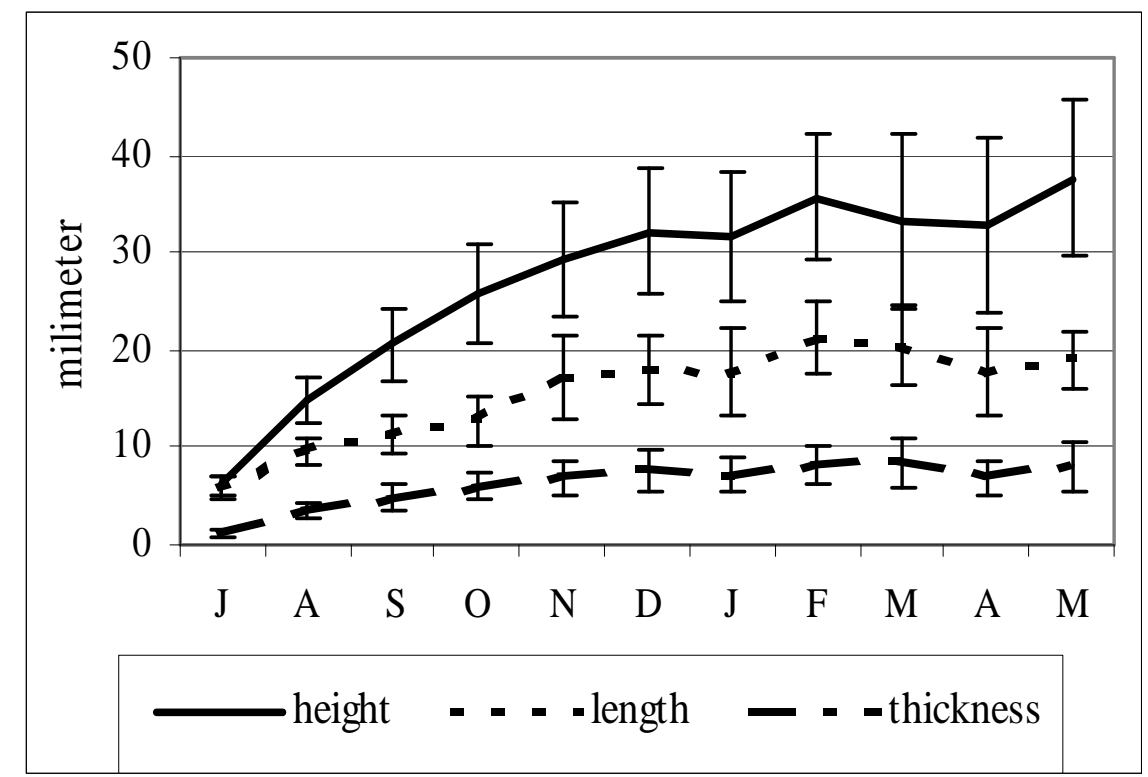

Figure 2 - Average size (mm) of oysters Crassostrea rhizophorae in cages at Piraquê-açu river estuary. 


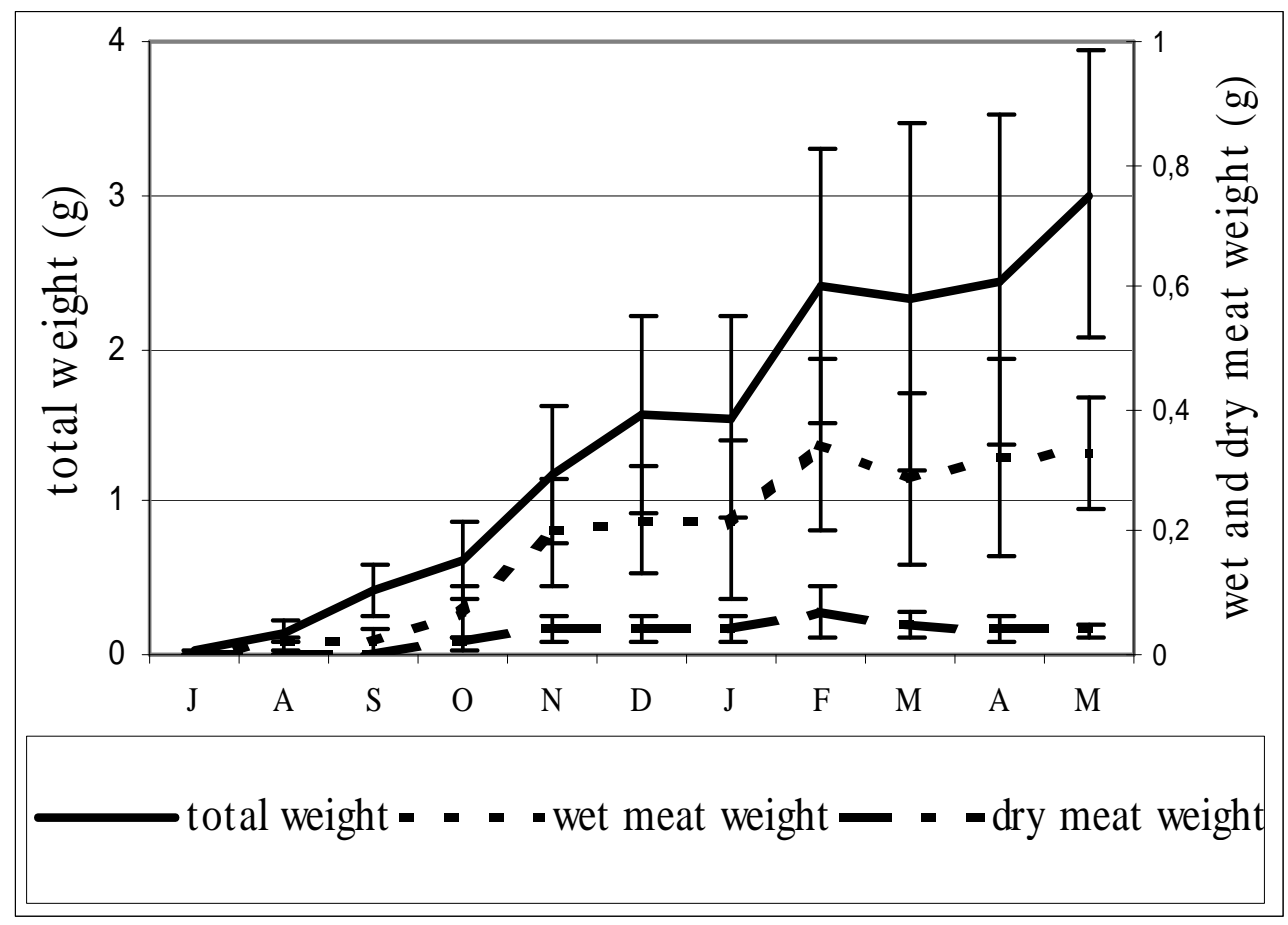

Figure 3- Average weight (g) of oysters C. rhizophorae in cages at Piraquê-açu river estuary.

Littlewood (1988) in Jamaica and Hernandez et al. (1998) in Venezuela also obtained oysters above $50 \mathrm{~mm}$ in six months, in salinities close or above 35 psu. However, Ramos et al. (1986) found that C. rhizophorae had grown to only $40 \mathrm{~mm}$ in height after one year in Baía de Todos os Santos, BA, and found difficulty to compare their data with different areas.

High water salinity (above $30 \mathrm{psu}$ ) at Piraquê-açu river estuary during experimental months (compared to other estuaries nearby, e.g. Vitória estuarine system) could be responsible for the low growth of oysters. Fernandes et al. (1983) observed a decrease in $C$. rhizophorae oyster size at Cururuca river estuary, Maranhão State, in high salinity locations. Vilanova and Fonteles-Filho (1989) also reported that oysters from Ceará river estuary were smaller than in other areas with low salinity, and they attributed the salinity as the primary cause of the reduced growth.

The presence of large numbers of dead oysters in our study area could also be due to high salinities: Pereira et al. (1988) stated that the best growth and survival in $C$. rhizophorae were in low salinities areas. The high mortality in our estuary could also be attributed to high numbers of predators mainly flatworms Stylochophana divae and carnivorous gastropods Cymatium parthenopeum, more frequent in May, which coincided with the highest mortality. According to Vélez (1991), C. parthenopeum was the most serious potential predator of oysters, as was also found in studies in Venezuela (Hernandes et al., 1998). The presence of fouling organisms in great numbers, mainly barnacles, tubicolous polychaete and oyster seeds probably affected the filtration rates and contributed to the low survival. Pereira et al. (1988), working with C. brasiliana, noticed that in high density the mussel Mytella falcata caused high oyster mortality.The decrease in wet and dry meat weight during March was probably related to reproduction, coinciding with the spawning peak as observed by Vélez (1991).

The high recruitment of oyster seeds (Fig. 5) probably was due to high water salinities. Nascimento (1991) found that the attachment of $C$. rhizophorae was higher in places with high salinities, although oyster growth rates were higher in brackish waters. Vilanova and Fonteles Filho (1989) also observed higher numbers of young oysters in drier months, when the salinity was higher. Our results suggested that lower salinity found in upriver areas (Barroso, 2004) could be a better environment for farming mangrove oyster, 
and the mouth of Piraquê-açu river estuary was a better place for spat collection. However, more research would be required, as salinities at this estuary could be exceptionally high due to El Niño phenomena as occurred in 1998-1999 (Costa and Nalesso, 2002).

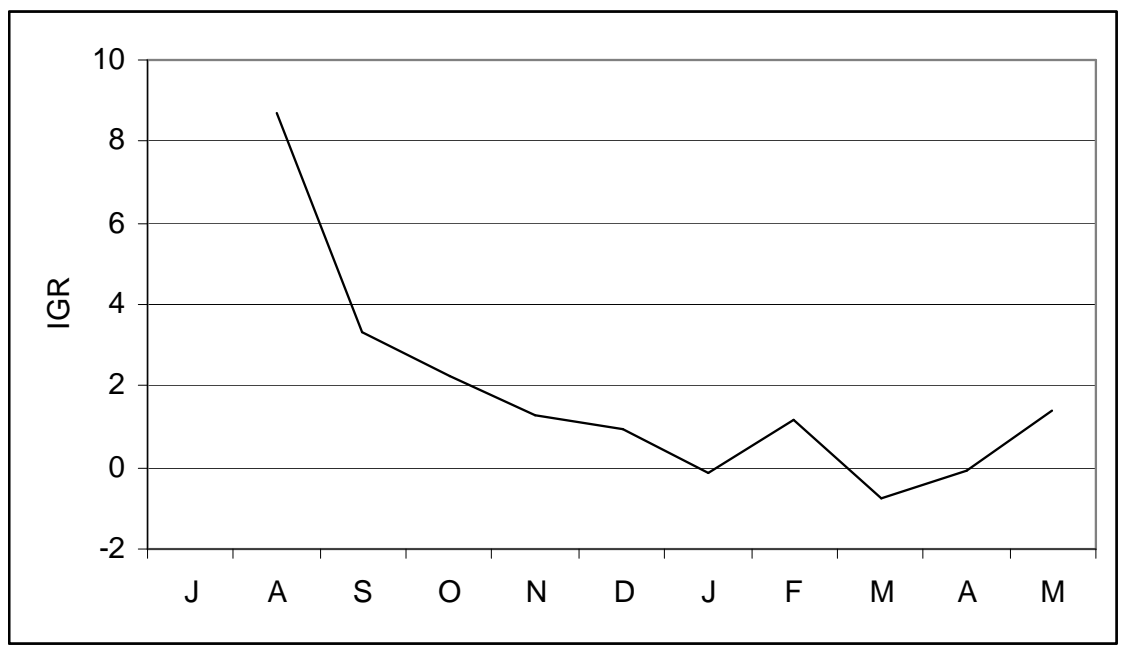

Figure 4 - Instantaneous growth rate (IGR) of the oysters Crassostrea rhizophorae at Piraquê-açu river estuary.

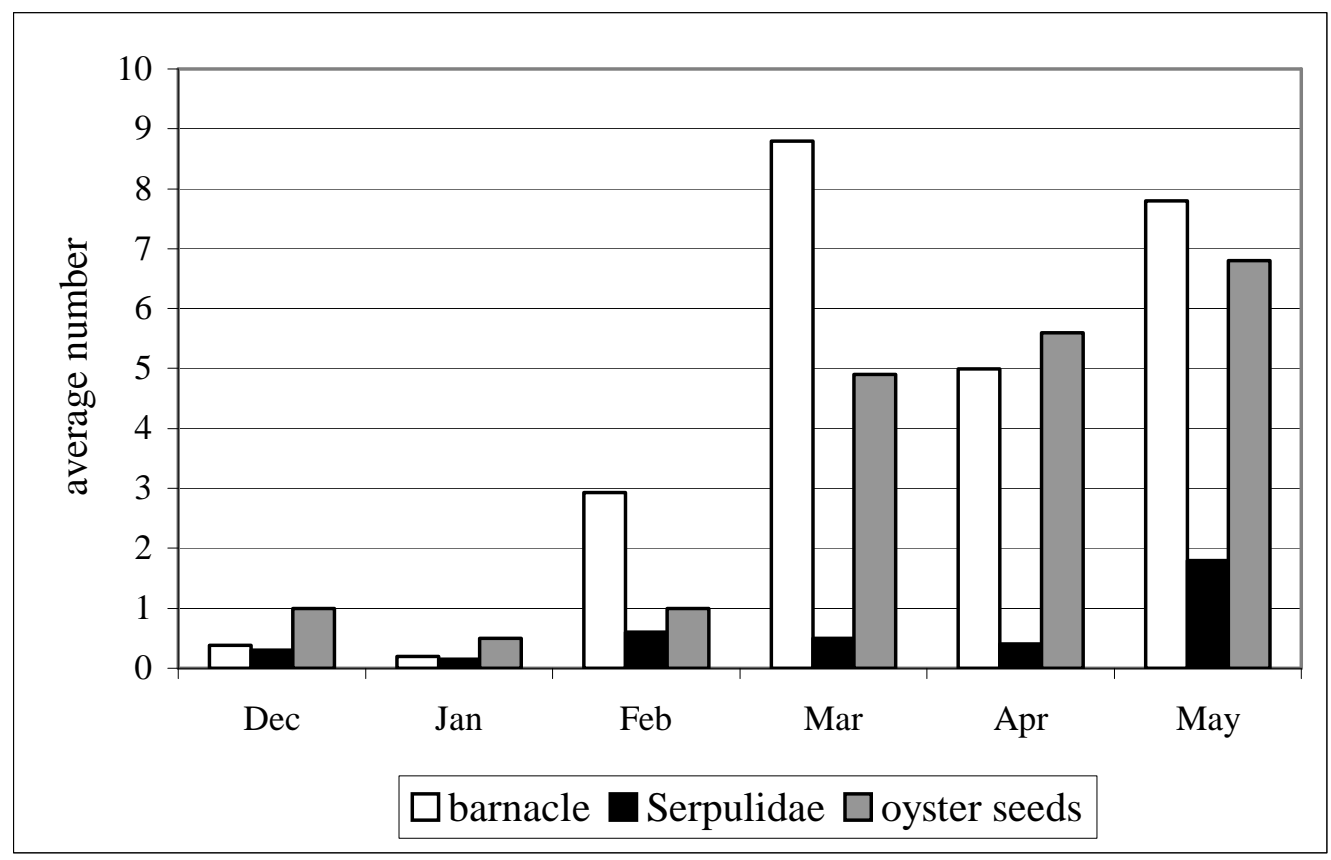

Figure 5 - Average number of the main fouling organisms per oyster Crassostrea rhizophorae at Piraquê-açu river estuary. 


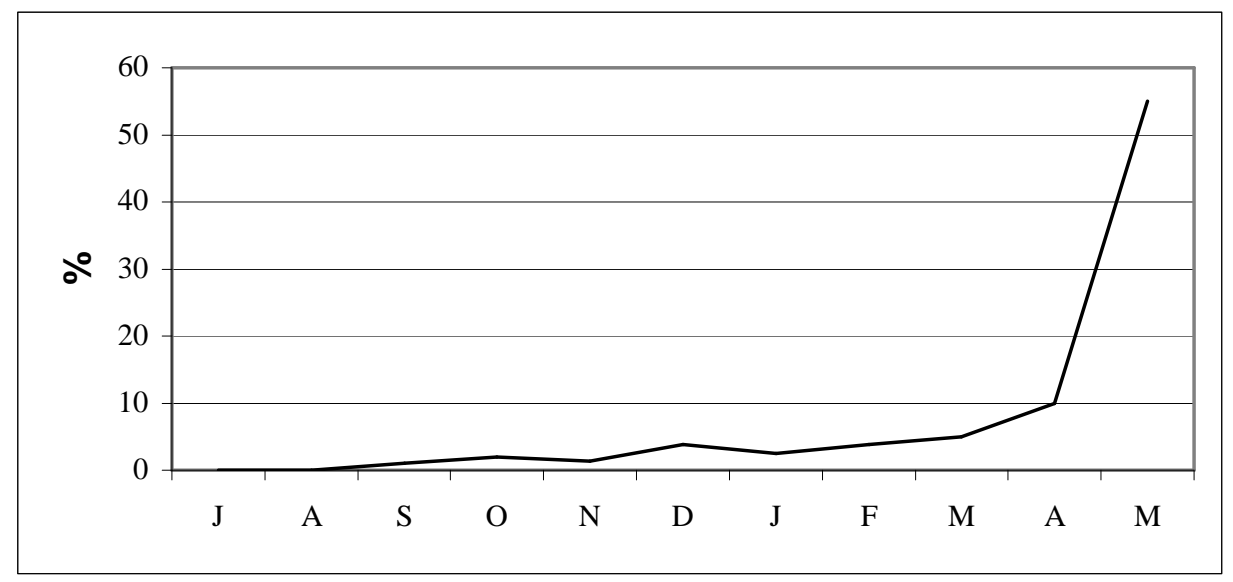

Figure 6 - Mortality rate from experimental oysters in cages at Piraquê-açu river estuary. $\mathrm{N}=80$ (except for March, when $\mathrm{N}=40$ ).

\section{ACKNOWLEDGEMENTS}

The first author would like to thank the Brazilian Mariculture Linkage Program-BMLP for the undergraduate scholarship. We would also like to thank to Dr. Gilberto F. Barroso for his help during the work; to Centro de Tecnologia em Aquicultura-CTA for the use of their facilities at Piraquê-açu river estuary; to Adrian R. Beech for revision in the English text, to the fisherman Sr. Pedro Melo and Wallace Melo for their help in field and an unknown reviewer for critically reviewing the manuscript.

\section{RESUMO}

No estuário do Rio Piraquê-açu, município de Aracruz, ES, foi avaliada a viabilidade técnica da implantação do cultivo de ostras Crassostrea rhizophorae em lanternas suspensas numa balsa de cultivo, através da estimativa de crescimento e ganho de peso fresco e seco das ostras. Verificouse que, durante os dez meses de cultivo (junho/98 a maio/99), as ostras atingiram, em média, 37,6 $\mathrm{mm}$ de altura e 3,0 $\mathrm{g}$ no peso total. Foi registrada uma alta taxa de mortalidade, que poderia ser atribuída aos altos valores de salinidade na água e também aos predadores observados como planárias Stylochoplana divae e gastrópodos Cymatium parthenopeum, além de incrustantes como cracas, poliquetos Serpulidae e principalmente sementes da própria ostra.

\section{REFERENCES}

Barardi, C. R. M. and Santos, C. S. (2001), Ostras de qualidade em Santa Catarina. Ciência Hoje, 29 : (172), 70-73.

Barroso, G. F. (2004), Development of an evaluation framework for sustainable bivalve aquaculture: a strategic plan approach in Espírito Santo, Brazil. PH Thesis, University of Victoria, Canadá.

Carmo, T. M. S. (1987), Os manguezais ao norte da Baía de Vitória, Espírito Santo. Simpósio sobre Ecossistemas da Costa Sul e Sudeste Brasileira. Publicações ACIESP, São Paulo, 54-I, 173-194.

Centro de Tecnologia em Aquicultura - CTA. (1996), Levantamento de áreas costeiras propícias ao cultivo de mariscos no litoral do Espírito Santo. Relatório Final do Projeto de Extensão e Difusão Tecnológica: Maricultura. SEBRAE-ES/FAES, Espírito Santo. 75 pp.

Costa, K. G. and Nalesso, R. C. (2002), Cultivo experimental de Mytella falcata (Orbigny, 1846) e $M$. guyanensis (Lamarck, 1819) no estuário do Rio Piraquê-açu, Aracruz, ES. Acta Limnologica Brasiliensia, 14, 15-22.

Fernandes, L. M. B.; Castro, A. C. L.; Fernandes, G. L.; Mendes, G. N. and Juras, I. A. G. M. (1983), Prospecção pesqueira: ostra do mangue (Crassostrea rhizophorae). In: Superintendência do Desenvolvimento da Amazônia. Caracterização ambiental e prospecção pesqueira do estuário do Rio Cururuca, Maranhão. Belém. 141 pp.

Fundação Instituto de Pesca do Estado do Rio de Janeiro - FIPERJ (1997), Manual para iniciação em ostreicultura. Rio de Janeiro, Brasil, 36pp.

Galtsoff, P. S. (1964), The American Oyster, Crassostrea virginica (Gmelin). US Fish and Wildlife Service Bulletin, 64, 430. 
Hernández, O. D.; Troccoli, L. G. and Millán, J. Q. (1998), Crecimiento, engorde y sobrevivencia de la ostra de mangle Crassostrea rhizophorae Guilding, 1828 en la Isla de Cubagüa, Venezuela. Caribbean Journal of Science, 34 : (3-4), 243-249.

Ignacio, B. L.; Absher, T. M.; Lazoski, C. and SoléCava, A. M. (2000), Genetic evidence of the presence of two species of Crassostrea (Bivalvia: Ostreidae) on the coast of Brazil. Marine Biology, 136, 987-991.

Lemos, M. B. N.; Nascimento, I. A.; Araújo, M. M. S.; Pereira, S. A.; Bahia, I. and Smith, D. H. (1994), The combined effects of salinity, temperature, antibiotic and aeration on larval growth and survival of the mangrove oyster, Crassostrea rhizophorae. Journal of Shellfish Research, 13, 187-192.

Littlewood, D. T. J. (1988), Subtidal versus intertidal cultivation of Crassostrea rhizophorae. Aquaculture, 72, 59-71.

Miranda, M. B. B. and Guzenski, J. (1999), Cultivo larval da ostra do mangue, Crassostrea rhizophorae (Guilding, 1828), em diferentes condições de temperatura, salinidade e densidade. Arq. Ciên. Mar, Fortaleza, 32, 73-84.

Nascimento, I. A. (1982), Cultivo de ostras no Brasil: problemas e perspectivas. Cienc. Cult. (Maracaibo), 35, 871-876.

Nascimento, I. A. (1991), Crassostrea rhizophorae (Guilding) and C. brasiliana (Lamarck) in South and Central America. In: Menzel, W. (Ed.). Estuarine and marine bivalve mollusk culture. Boston: CRC Press. pp.125-134.

Nascimento, I. V.; Santos, E. P.; Costa, F. J. C. B. and Sá, M. F. P. (1980), Análise quantitativa no cultivo de Crassostrea rhizophorae (Guilding, 1828). B. Núcl. Est-s Ci-s Mar. Maceió, 3, 21-27.
Pereira, O. M.; Akaboshi, S. and Soares, F. C. (1988), Cultivo experimental de Crassostrea brasiliana (Lamarck, 1819) no canal da Bertioga, São Paulo, Brasil $\left(23^{\circ} 54^{\prime} 30^{\prime \prime S}, 45^{\circ} 13^{\prime} 42^{\prime \prime W}\right)$. B. Inst. Pesca São Paulo, 151, 55-65.

Ramos, M. I. S.; Nascimento, I. A. and Silva, J.L. (1986), The comparative growth survival of pacific oyster (Crassostrea gigas var. Kumamoto) and mangrove oyster (C. rhizophorae) in Todos os Santos Bay, Brazil. Ciência e Cultura, 38 : (9), 1604-161.

Ricker, W. E. (1975), Computation and interpretation of biological statistics of fish populations. Bulletin of the Fisheries Research Board of Canada, 191, 1-382.

Rios, E. (1994), Seashells of Brazil. $2^{\text {nd }}$ ed. Rio Grande: FURG.

Vélez, A. (1991), Biology and culture of the Caribbean mangrove oyster, Crassostrea rhizophorae, Guilding, in the Caribbean and South América. In: Menzel, W. ed. Estuarine and marine bivalve mollusk culture. Boston: CRC Press. pp. 117-124.

Vilanova, M. F. V. and Fonteles-Filho, A. A. (1989), Análise da biometria e do fator de condição da ostra-do-mangue, Crassostrea rhizophorae (Guilding, 1828) (Mollusca, Bivalvia) no estuário do rio Ceará, Ceará, Brasil. Ciência e Cultura, 41 : (11), 1117-1124.
Received: August 04, 2003; Revised: September 23, 2004; Accepted: August 05, 2005. 